\title{
New Crushing Strength Formula of Aluminum Honeycomb with Thinning Cell Wall
}

\author{
Nagahisa OGASAWARA*4, Norimasa CHIBA, Masuhiro BEPPU, \\ Yoichi KAWASHIMA, Eiji KOBAYASHI and Yuji KIKUCHI \\ ${ }^{* 4}$ Department of Mechanical Engineering, National Defense Academy,
1-10-20 Hashirimizu, Yokosuka-shi, Kanagawa, 239-8686 Japan
}

An aluminum honeycomb which has etched cell wall is ued as a shock absorbent material for the offset frontal collision test and the side collision test of automobile. In this study, based on the analyses of the shock absorption mechanism, a new crushing strength formula is proposed. Firstly, load-displacement curves obtained from compression tests in quasi-static condition showed almost linear relation between a thinning rate of cell walls $R$ and a crushing strength. Secondly, based on Wierzbicki's theory, a new formula was proposed, which can estimate a crushing strength of honeycomb material with thinning wall. Thirdly, parametric analyses were carried out with FEM model which can simulate a delamination between cell walls. The results which were obtained from theory and FEM almost corresponded to each other for a wide range of core ratio. The proposed formula works well for $R<70 \%$. Impact tests were carried out, in which the weight was dropped freely at the speed used for automobile tests. Those results almost agreed well with the sum of the theoretical crush strength and the inside air pressure.

Key Words: Impact Strength, Buckling, Finite Element Method, Theoretical Solution, Etching, Quasi-Static Condition, Dynamic Condition, Hexagonal Cell Structure, Crushing Strength

\section{1. 緒 言}

自動車の衝突安全性を確保するために，様々な条件 で衝突試験が行われている. 自動車対自動車の衝突を 想定したオフセット衝突試験および側面衝突試験では, 試験車体に対する衝突物に剛体壁を用いず，変形体の アルミニウム製ハニカム材料を用いている(1)(2).これは 八ニカム材料が，軸方向（図 1 の Z 軸方向）荷重を与 えられた時に逐次圧潰座屈し，不可逆的で安定した衝 撃吸収を行うことができるからである(3). 近年の衝突 試験では，自動車同士の衝突現象をより正確に再現す る目的で, 衝突物の圧潰荷重値が変形に伴って増加す るように求められている(1). 同一形状の八二カム材料 は一定の圧潰荷重值を持つため ${ }^{(4)(5)}$, セルサイズや箔厚 などの形状を変えたハ二カム材料を多段積層させ，階 段状の荷重一変位関係を作り対応してきた (6(7). しかし

\footnotetext{
* 原稿受付 2008 年 4 月 2 日. 10-20).

*2 防衛大学校建設環境工学科.

*3 横浜ゴム (株) (拜 254-8601 平塚市追分 2-1).

E-mail : oga@nda.ac.jp
}

*1 正員, 防衛大学校機械工学科(严 239-8686 横須賀市走水 1-
この方法では, 構造が複雑になり重量が増す等の欠点 があった．そこで現在は，セル壁を化学薬品でエッチ ング処理し, 箔厚を連続的に変化させた一体型の減肉 八二カム材料が普及している. 一方で, 減肉八二カム 材料の衝撃吸収特性は十分に明らかにされておらず(8), 試験規準を満たすハニカム材料を経験的に選択してい る現状がある.

本研究では，実験，理論解析および数值実験を用い て減肉ハニカム材料の衝撃吸収特性を明らかにし, 减 肉ハニカムの形状パラメータと圧潰荷重の関係式を作 成することを目的とする.

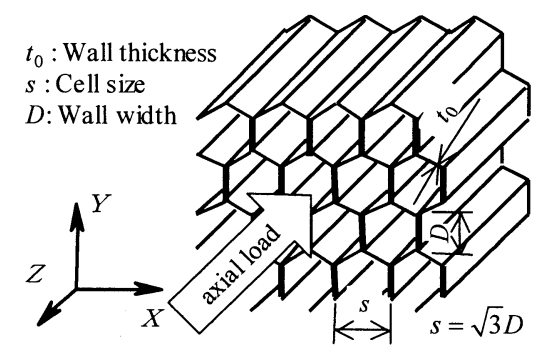

Fig. 1 Schematic of honeycomb material 


\section{2. 準静的実験}

減肉ハ二カム材料の圧潰特性を調べるために，万能 試験機を用いて準静的圧潰実験を行った．試験片は， 一般的な八二カム材料で用いられている JIS Al3003 材 製と JIS A15052 材製の 2 種類を用意した。試験片寸法 と引張圾験にて得られた簿材の材料定数を表 1 に示す。 箔材の引張試験は, 八ニカム材料に用いられる䈃を JIS K6251 に定められた形状に切り出し, $10 \mathrm{~mm} / \mathrm{min}$ の引 張速度で実施した．表 1 中の $n$ は引張試験の結果をべ き乗硬化則にあてはめた際の加工硬化指数を表す．減 肉処理前の馢厚 $t_{0}$ は, それぞれ $45 \mu \mathrm{m}$ と $76 \mu \mathrm{m}$ であり， 試験片最上部から定められた高さ $Z_{\mathrm{e}}$ までの篞に対し， エッチングによる減肉処理をしている. デジタルイン ジケータおよびレーザ顕微鏡を用いて䇴厚計測したと ころ，外周部と内部の䇴厚むらは存在せず，最上部か ら $Z_{\mathrm{e}}$ までの区間ではほぼ線形に箔厚変化していた。 ま た, 圧潰初期のピーク荷重発生を避けるため, 最上部 $10 \mathrm{~mm}$ をあらかじめ座屈変形させた. 変形時に内部空 気の圧力増加を防ぐため，八ニカム材料の上下を挟む 表面板の片方（下部）には，直径 $8 \mathrm{~mm}$ の孔が $12 \mathrm{~mm}$

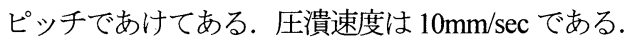

準静的圧潰実験における圧潰荷重と変位の関係を図 2 内に太実線で示す． $0 \sim Z_{\mathrm{e}}$ までの区間では，䇴厚の薄 い位置から順に圧潰し, 圧潰荷重值はほぼ線形増加し ている，また，䇴厚一定となる $Z_{\mathrm{e}}$ 以降は，圧潰荷重値 が一定值に落ち着いている。

Table 1 Specification of specimens

\begin{tabular}{|c|c|c|c|}
\hline \multicolumn{2}{|c|}{} & Al 3003 & Al 5052 \\
\hline Width $: X$ & $(\mathrm{~mm})$ & \multicolumn{2}{|c|}{500} \\
\hline Length $: Y$ & $(\mathrm{~mm})$ & \multicolumn{2}{|c|}{250} \\
\hline Height $: Z$ & $(\mathrm{~mm})$ & \multicolumn{2}{|c|}{500} \\
\hline Cell size $: s$ & $(\mathrm{~mm})$ & \multicolumn{2}{|c|}{19.05} \\
\hline Min. wall thickness $: t_{1-\min }$ & $(\mu \mathrm{m})$ & 13 & 1 \\
\hline Max. wall thickness $: t_{0}$ & $(\mu \mathrm{m})$ & 45 & 76 \\
\hline Etched height $: Z_{\mathrm{e}}$ & $(\mathrm{mm})$ & 230 & 300 \\
\hline Young's modulus $: E$ & $(\mathrm{GPa})$ & \multicolumn{3}{|c|}{71} \\
\hline Yield stress: $\sigma_{\mathrm{y}}$ & $(\mathrm{MPa})$ & 185 & 284 \\
\hline Work hardening exponent $: n$ & & 0.15 & 0.05 \\
\hline
\end{tabular}

\section{3. 理論解析}

\section{$3 \cdot 1$ Wierzbicki 理論解(9)の修正 箔厚を減肉さ} せていないハニカム材料の圧潰荷重値については, Wierzbicki が理論式を提案している. 八ニカム材料の 周期性を考慮した単位要素から，逐次圧潰座屈の折れ 幅 1 周期分の高さ $2 H$ だけを切り出した”く”の字形 モデルを用いて，変形機構を解明している. 図 3 にモ デルの形状を示す，実際は，一対のモデルが $\overline{\mathrm{OB}}$ を含
む面で背中合わせに貼り合わされた形状で変形してい る.つまり $\overline{\mathrm{OB}}$ を含む面は 2 枚重ねになっており, $\overline{\mathrm{OA}}$ を含む面の 2 倍の簿厚である. 以下 3 種類の曲げ変形 機構によりエネルギーを吸収していると想定している.

$\mathrm{E}_{1}$ : 点 $\mathrm{O}$ における塑性ヒンジ

$\mathrm{E}_{2}: \overline{\mathrm{OA}}, \overline{\mathrm{OB}}$ 上の塑性ヒンジ

$\mathrm{E}_{3}: \overline{\mathrm{OC}}, \overline{\mathrm{OD}}$ 上の塑性ヒンジ

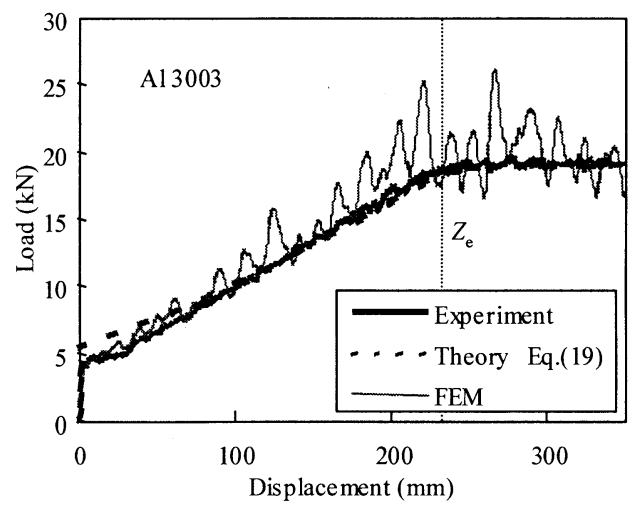

(a) $\mathrm{Al} 3003$

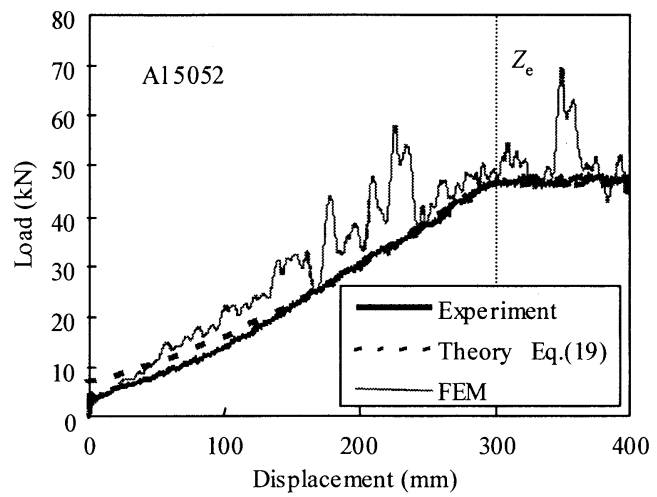

(b) $\mathrm{Al} 5052$

Fig. 2 Load vs. displacement in quasi-static condition

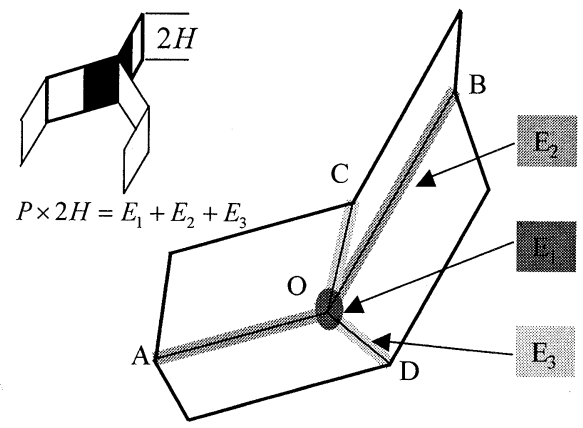

Fig. 3 L-shaped model which shows mechanism of energy absorption 
これら全ての変形は McFarland ${ }^{(10)}$ が提唱した面内の せん断変形を伴わず，箔の曲げ変形だけで八ニカム材 料全体の圧潰が進んでいく，著者等は準静的実験のマ イクロスコープ観察により, 圧潰変形時には六角セル の頂点で接着はく離が起こっており，せん断変形が小 さく抑えられていることを確認した(3).

八ニカム材料の素材を, 降伏応力が $\sigma_{0}$ の剛一完全塑 性体と仮定すると, 䈃厚 $t$ の馢における単位長さあた りの曲げモーメントは $M=\sigma_{0} t^{2} / 4$ で表される. 3 種類 の変形機構において, 曲げ変形の幾何学的条件を考慮 すると，一対の”く”の字形モデルで吸収されるエネ ルギーは以下で表される. なお変形機構 $\mathrm{E}_{\mathrm{i}}$ で吸収され るエネルギーを $E_{\mathrm{i}}$ とする.

$$
\begin{aligned}
& E_{1}=33.6 M \frac{H b}{t}=8.4 \sigma_{0} t H b \\
& E_{2}=6 \pi D M=\frac{3 \pi}{2} \sigma_{0} t^{2} D \\
& E_{3}=19.12 M \frac{H^{2}}{b}=4.78 \sigma_{0} t^{2} \frac{H^{2}}{b}
\end{aligned}
$$

$t$ は箔厚, $D$ は六角形セル壁の辺の長さ $(\overline{\mathrm{OA}}=D / 2), b$ は折れ曲がり部の曲率半径である.

Wierzbicki の理論式では, 変形機構 $\mathrm{E}_{2}$ で吸収される 単位長さあたりのエネルギーは, $E_{2}=M \pi / 2$ で表される. また $\overline{\mathrm{OA}}$ 等の折れ曲がり線 1 つに対し 2 つの塑性ヒン ジが生じると仮定している. 一対のモデル内では馢厚 $t$ の部分で 8 本, 䇴厚 $2 t$ の部分で 4 本の塑性ヒンジが 生じていると述べられているが，4 本と 2 本の間違い と思われる. この点を修正すると式(2)は半分の值とな り, 一対の” く”の字形モデル内において変形機構 $\mathrm{E}_{2}$ で吸収されるエネルギーは次式で表される。

$$
E_{2}=3 \pi D M=\frac{3 \pi}{4} \sigma_{0} t^{2} D
$$

一対の” く” の字形モデル（高さ $2 H$ ) が圧潰する際 の平均荷重值を $P$ とすると, 次式が成立する.

$$
P \times 2 H=E_{1}+E_{2}+E_{3}
$$

吸収エネルギーを最小に抑えるよう未知数 $H, b$ を 決定するためには式(6)が成立し, 結果として $H, b$ が 式(7)と式(8)として導かれる.

$$
\begin{aligned}
& \frac{\partial P}{\partial H}=0, \frac{\partial P}{\partial b}=0 \\
& H=0.517 \sqrt[3]{D^{2} t} \\
& b=0.543 \sqrt[3]{D t^{2}}
\end{aligned}
$$

式(5)に式(1)，(3)，(4)及び式(7)，(8)を代入し整理する と, 一対の” く”の字形モデルあたりの平均圧潰荷重 值(9)が得られる.

$$
\overline{P_{s 0}}=6.83 \sigma_{0} \sqrt[3]{t^{5} D}
$$

一対の”く”の字形モデルが占める受荷面積は,

$$
A=\frac{\sqrt{3}}{4} s^{2}=\frac{3 \sqrt{3}}{4} D^{2}
$$

で示され, 単位面積あたりの平均圧潰荷重値は次式 (11)で表される.

$$
\overline{\sigma_{s 0}}=13.07 \sigma_{0}\left(\frac{t}{s}\right)^{5 / 3}
$$

式(11)の係数は, Wierzbicki の理論式の係数 16.56 に対 し, 約 0.8 倍となった. 著者らは準静的圧潰実験と有 限要素法による数值実験により, Wierzbicki の理論式 が様々なコア密度 $t / s$ に対し成立することを確認して いる(3). この時の流動応力 $\sigma_{0}$ は, 文献(9)に従い引張強 さの 0.7 倍としたが, Wierzbicki の理論式に代わり式 (11)を利用する際は, 流動応力に引張強さの約 0.9 倍を 採用すれば同等の結果が得られる.

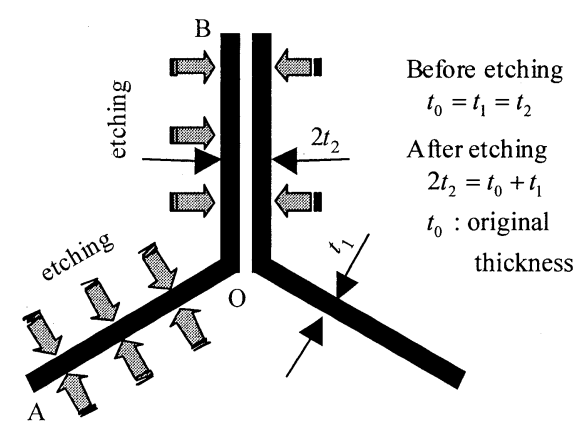

Fig. 4 Schematic of etching process

$3 \cdot 2$ 減肉ハニカム材料の理論解 図 4 はエッチ ングと䇴厚の関係を簡易的に示したものである．展張 法で作られたハニカム材料は， $\overline{\mathrm{OB}}$ 間の䇴が 2 枚重ね になっているため, $\overline{\mathrm{OA}}$ 間の 2 倍の䇴厚を持つ. しか し, エッチング処理により減肉されたハニカム材料で は, 2 枚重ね部の内部が減肉処理されないため, 2 枚重 ね部 $\overline{\mathrm{OB}}$ と 1 枚部 $\overline{\mathrm{OA}}$ では, 箔厚 1 枚あたりの減肉量 が異なる. よって減肉処理後は, 以下の筞厚関係が成 立する.

$$
2 t_{2}=t_{0}+t_{1}
$$

ここで $t_{0}$ は減肉前の箔厚である. 減肉処理が進むと, $t_{1}$ と $t_{2}$ は大きく異なるため, Wierzbicki の単位面積あた りの平均圧潰荷重理論式(11)は減肉八二カム材料の圧 
潰現象には適用できない，そこで，エッチングによる 減肉を考慮した新しい式の構築が必要となる.

前節の準静的実験の観察により, 減肉八二カム材料 においても，エネルギーを吸収する変形機構は変わら ないことを確認している，そこで新しい評価式を作成 する上で，Wierzbicki の理論を参考にする.

変形機構 $\mathrm{E}_{1}$ では, 変形が進むにつれ図 3 の点 $\mathrm{O}$ は移 動する. 一対の” く”の字形モデルにおいて，片方の” く”の字形モデルの点 $\mathrm{O}$ は点 $\mathrm{A}$ に向かい，もう一方の モデルでは点 $\mathrm{B}$ に向かう. 式(1)に示されたエネルギー を $\overline{\mathrm{OA}}$ 側と $\overline{\mathrm{OB}}$ 側が半分ずつ負担することになり，そ れぞれの箔厚を考慮すると式(13)が得られる。この際， 変形前の $\overline{\mathrm{OB}}$ は2枚重ねであり䇴厚は $2 t_{2}$ で表されてい たが，変形時にはく離していることから，箔厚が $t_{2}$ と なっていることに注意が必要である. 変形機構 $\mathrm{E}_{3}$ も同 様に考えられ, 式(15)が得られる. 一方, 変形機構 $\mathrm{E}_{2}$ では，接着はく離していない部分のエネルギー吸収を 対象としている.一対の”く”の字形モデル内では, $\overline{\mathrm{OA}}$ は 2 箇所に存在するため $\overline{\mathrm{OB}}$ の 2 倍の長さである.ま た $\overline{\mathrm{OB}}$ の䇴厚は $2 t_{2}$ である. このため式(14)が得られる.

$$
\begin{aligned}
& E_{1}=4.2 \sigma_{0}\left(t_{1}+t_{2}\right) H b \\
& E_{2}=\frac{\pi}{4} \sigma_{0}\left\{4 \frac{t_{1}^{2}}{4}+2 \frac{\left(2 t_{2}\right)^{2}}{4}\right\} D=\frac{\pi}{4} \sigma_{0}\left(t_{1}^{2}+2 t_{2}^{2}\right) D \\
& E_{3}=2.39 \sigma_{0}\left(t_{1}^{2}+t_{2}^{2}\right) \frac{H^{2}}{b}
\end{aligned}
$$

前節と同様に吸収エネルギーを最小に抑えるよう未知 数 $H, b$ を決定寸ると, 式(16)と式(17)が導かれる.

$$
\begin{aligned}
& H=0.395 \sqrt[3]{\frac{D^{2}\left(2 t_{1}^{2}+t_{2}^{2}\right)^{2}}{\left(t_{1}+t_{2}\right)\left(t_{1}^{2}+t_{2}^{2}\right)}} \\
& b=0.474 \sqrt[3]{\frac{D\left(2 t_{1}^{2}+t_{2}^{2}\right)\left(t_{1}^{2}+t_{2}^{2}\right)}{\left(t_{1}+t_{2}\right)^{2}}}
\end{aligned}
$$

式(5)に式(13)-(17)を代入すると一対の” く”の字形モ デルあたりの圧潰荷重值(18)が得られる.

$$
P_{s}=2.99 \sigma_{0} \sqrt[3]{\left(t_{1}+t_{2}\right)\left(t_{1}^{2}+t_{2}^{2}\right)\left(t_{1}^{2}+2 t_{2}^{2}\right) D}(18)
$$

一対の” く”字形モデルが占める受荷面積(10)で除 し, 単位面積あたりの圧潰荷重値は式(19)となる.

$$
\sigma_{s}=5.74 \sigma_{0}\left(\frac{t_{0}}{s}\right)^{5 / 3} \sqrt[3]{\frac{\left(t_{1}+t_{2}\right)\left(t_{1}^{2}+t_{2}^{2}\right)\left(t_{1}^{2}+2 t_{2}^{2}\right)}{t_{0}^{5}}}
$$

材料を剛一完全塑性体と仮定し作成した上式を実際 の弾塑性材料に適用するためには， $\sigma_{0}$ を逐次座屈圧潰 変形場のある種の平均応力, すなわち流動応力として 扱う必要がある. 一方で減肉八ニカム材料は軸方向で 䇴厚が変化しており, それぞれの変形過程で流動応力 は異なる. 以下に, 䇴厚と流動応力の関係を定義する.

板を曲げる際の平均ひずみは, 曲率半径 $b$ 式(17)と 平均箔厚 $t=\left(t_{1}+t_{2}\right) / 2$ を用いて, 式(20)で表される.

$$
\varepsilon_{a v}=\frac{t}{4 b}
$$

八ニカム材料に用いられるアルミニウム材は延性に 富み，応力ひずみ関係においてべき乗硬化則が成立す る. よって, 流動応力は次式で表される.

$$
\sigma_{0}=\sigma_{y}\left(\frac{E}{\sigma_{y}} \varepsilon_{a v}\right)^{n}=\sigma_{y}\left(\frac{t E}{4 b \sigma_{y}}\right)^{n}
$$

ここで $E$ はヤング率， $\sigma_{\mathrm{y}}$ は降伏応力， $n$ は加工硬化指 数である. 結果として, 流動応力は䇴厚の関数として 表すことができる.

準静的実験で用いた試験片の最上面の平均箔厚 $t_{\text {min }}$ は, $\overline{\mathrm{OA}}$ 部と $\overline{\mathrm{OB}}$ 部の最小管厚 $t_{1-\text { min }}$ と $t_{2 \text {-min, }}$, さらに工 ッチングしたハニカム材料の簿厚関係式(12)を用いて 以下の式で表される.

$$
t_{\min }=\frac{t_{1-\min }+t_{2-\min }}{2}=\frac{t_{0}+3 t_{1-\min }}{4}
$$

試験片の䇴厚は最上部から $Z_{\mathrm{e}}$ の高さまでほほ線形に変 化していることから, 高さ $Z$ における平均箔厚 $t_{z}$ は次 式で表される.

$$
t_{z}=\frac{t_{0}-t_{\min }}{Z_{e}} Z+t_{\min }, \quad\left(Z \leq Z_{e}\right)
$$

式(23)および表 1 の材料定数を式(21)に代入し高さ $Z$ における流動応力を求め, さらに式(19)に代入するこ とで, 各高さ $Z$ における理論圧潰荷重值を求めた. Al3003 材および Al5052 材の理論值を, 図 2 に破線で 示す.

準静的実験で得た圧潰荷重值と比較したところ，変 形量が大きい区間，具体的には減肉率 $R=\left(t_{0}-t_{1}\right) / t_{0}$ が約 65 70\%以下の区閒では，理論值は誤差 $10 \%$ 以下の良 好な值を示している. 減肉率 $R$ が大きい，薄い箔厚の 時は，曲げ変形によるひずみが小さく，全ひずみにお ける弾性ひずみの割合が相対的に大きくなる．本理論 解は剛-完全塑性体を対象にしており弾性変形を考慮 していないため, 減肉率が大きい場合の誤差が生じた と考えられる. 


\section{4. 有限要素解析}

$4 \cdot 1 \quad 1 / 6$ 接着はく離モデル 著者等は, 䈃厚を減 肉させていない八ニカム材料の圧潰現象を, 数值実験 で再現できる有限要素モデルを提案している( ${ }^{(3)}$. 幾何 学的周期性から六角形の $1 / 6$ を切り出した Y 字形状を 持ち，2 枚重ねの䇴が圧潰時にはく離を起こすようモ デリングされている.

この $1 / 6$ 接着はく離モデル (図 5) を用いて, 箔厚や セルサイズを変化させたパラメトリック数值実験を行 い, 理論解の検証を行った. 有限要素解析ソフトは LS-DYNA を使用した. 要素分割には, 4 節点シェル要 素を用いている．2枚重ねのセル壁部分は，向かい合 う節点間の自由度を互いに拘束している. 節点間力が, 入力した閾值より大きくなると拘束が解かれるよう設 定し, 接着はく離を模擬した. 接着はく離閾值は, JIS K6854 接着剂のはく離接着強さ試験法に基づいた実験 により決定している．側端面には対称性を考虑した境 界条件を与えた. また箔厚の $10 \%$ に相当する変位を, 初期不整として最上面の節点に与えている. 初期不整 用変位の方向を, 図 5 に白抜き矢印にて示寸.

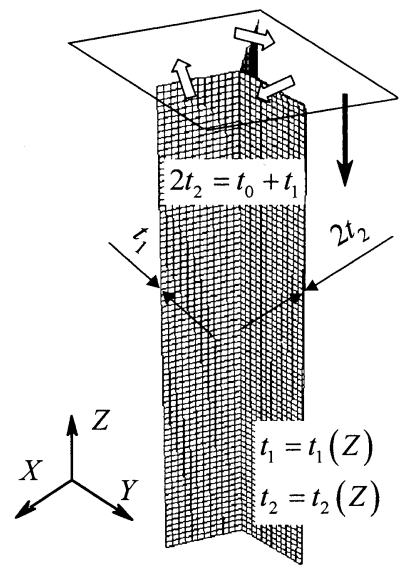

Fig. $5 \quad 1 / 6$ adhesive model for FEM simulation

\section{$4 \cdot 2 \quad 1 / 6$ 接着はく離モデルの減肉ハニカム材料への}

適用まず，2 節で用いた試験片形状を模したモデ ルを作成し, 準静的圧潰試験を行った. 箔厚が, 高さ に応じて連続的に変化するように, 要素 1 つ 1 つに異 なる䈃厚を定義している．また2 枚重ねのセル壁のシ エル要素間隔は箔厚 $t_{2}$ と等しい. 材料定数は表 1 に示 した值を用い，応力ーひずみ曲線を真応力一対数ひず み曲線に変換した後, 多直線近似し入力した.

数值実験で得られた值を図 2 に示し, 実験值および 理論解と比較した. 実験初期および $Z_{\mathrm{e}}$ 以上では誤差の
小さな良好な結果が得られているが，䇴厚が線形変化 している区間においては誤差の大きい箇所がある。振 動の中間值を数值実験值とすると最大 $30 \%$ 程度の誤差 である.これは，モデルの細長さ比が非常に大きいこ とに起因寸る全体座屈モードの影響, 䇴厚の連続的変 化による座屈モードの変化, 䈃厚 $t_{1}$ と箔厚 $t_{2}$ の座屈モ 一ドの違い, 応力波の発生などが影響し, 座屈モード が一時的に乱れることが原因と思われる. 著者等は文 献(3)において, 異なる初期不整などにより生じた座屈 モードの乱れが, 本モデルの圧潰荷重值を上昇させる ことを明らかにしている. また, 大きい振幅が示す波 長は折れ幅 $2 H$ に対応している. 1 つの $\mathrm{Y}$ 字形モデル を対象とする数值実験では, 変形に伴い荷重值が大き く変動するが, 一方で無数の八ニカムセルを含む準静 的実験では, 荷重の変化は平均化され, 結果として安 定した荷重変位曲線が得られている.

$4 \cdot 3$ パラメトリック数値実験 理論式の適用範 囲を確認するために, コア密度 $t / s$ と減肉率 $R=\left(t_{0}-t_{1}\right) / t_{0}$ を変化させた減肉八二カム材料に対し準静的圧潰実験 を行い，理論式の結果と比較した. パラメータの多い 八ニカム材料は，多種類の試験片を用意することが難 しいため, 本モデルによる数值実験で代用する. コア 密度の範囲は, 工業利用されている $t_{0} / s=2.4 \times 10^{-3} \sim$ $2.4 \times 10^{-2}$ である. 素材材料はA 15052 を用いた. 数值実 験モデルは, セル壁厚の関係が式(12)を満たし, かつ セル壁厚の勾配を持たない.つまり $Z$ 方向に一定の馢 厚のハニカムモデルである. 管厚が一定のため圧潰荷 重值もほぼ一定となる.高さ $100 \mathrm{~mm}$ のモデルを圧潰し, その平均荷重值を圧潰荷重值として採用した. 本節で 使用したモデルは, 細長さ比が前節のモデルより十分 小さく, また箔厚勾配を持たないため比較的安定した 座屈現象を再現した.

図 6 に結果を示寸. 数值実験值と理論解は, 减肉率 $R<70 \%$ において誤差 $10 \%$ 以内である. 減肉率が大きい 場合に誤差が大きいことは，前章で述べたように弾性 変形の影響と考えられる. 本研究で提案する理論解は, 減肉率 $70 \%$ 以上の八ニカム材料において利用できるこ とが示された。

\section{5. 街撃実験}

$5 \cdot 1$ 落鍾式大型街撃試験自動車の衝突試験で は, $15.3 \mathrm{~m} / \mathrm{s}(=55 \mathrm{~km} / \mathrm{h})$ または $17.8 \mathrm{~m} / \mathrm{s}(=64 \mathrm{~km} / \mathrm{h})$ で 八ニカム材料を圧潰する. 衝撃吸収時の減肉ハニカム 材料の変形機構を確認するために衝撃実験を行った. 試験機は, 落錘式大型衝撃試験装置を利用した. 最大 質量 $3000 \mathrm{~kg}$ の落錘を最大落下高さ $28 \mathrm{~m}$ から自由落下 
（最大衝突速度 $24 \mathrm{~m} / \mathrm{s}$ ）することが出来る. 図 7 に試 験の概略を示す、落錘は衝突面が大きく傾かない上う ガイドレールに沿って落下し, 試験片直上の 2 点間の 通過時間を計測することで衝突速度を求めた。試験片 下のロードセルにより圧潰荷重値を測定し, 試験片横 に設置した高速度カメラにより変位を測定した. また, 試験片とロードセルの間には, 圧潰時にハニカム内部 の空気が流出するように，溝付の空気抜き板を挿入し た. 溝は幅 $8 \mathrm{~mm}$, 深さ $4 \mathrm{~mm}$ の矩形形状で, ピッチ $22 \mathrm{~mm}$ で図 1 の $Y$ 方向に条線上に配置した. 試験片形状は準 静的試験と同じである.

図 8 に荷重-変位関係の例を細実線で示す．実験 で得られた值は振動が激しいため, 文献(1)で定め られたローパスフィルターCFC60(ISO6487)を適用 した. 大きい振幅が示す波長は, 折れ幅に完全に 対応するものではない. 落錘質量は Al3003 材が $63 \mathrm{~kg}, \mathrm{~A} 15052$ 材が $109 \mathrm{~kg}$, 落下速度は $15.3 \mathrm{~m} / \mathrm{s}$ で ある. 両実験とも箔厚が線形変化している区間で は, 圧潰荷重値もほぼ線形増加している.

$5 \cdot 2$ 理論解との比較 3 章で求めた準静的圧潰 条件の理論解を, 図 8 に太破線で示寸. 変形が進むに 連れ，準静的理論解と衝撃実験值の差は大きくなって いることが分かる.もし素材材料のひずみ速度依存性 や, 変形モード（折れ幅）の速度依存性がこの差の原 因であるならば，大きな速度を保持している変形初期 段階において,より大きな差を生じているはずである. このことから衝撃実験による荷重増加の原因は, 試験 片内部空気の圧力増加と考えられる ${ }^{(1)}$. 内部空気の圧 力増加分は, 試験片の変形前高さ $Z_{0}$, 変形量 $d$, 大気 圧 $p_{0}$ を用いて, 次式で理論的に計算される. なお本式 では試験片下部の空気抜き板からの空気の漏れはない ものと仮定している.

$$
p=\frac{d}{Z_{0}-d} p_{0}
$$

図 8 に, 体積变化に伴う内部空気の圧力増加曲線を細 点線で示すとともに, 理論式(19)に空気の圧力増加分 式(24)を足した式(25)を太実線で示した.

$$
\sigma_{d}=\sigma_{s}+p
$$

衝撃実験の結果と, ·空気の圧力増加分を足した理論 解は, 箔厚が線形変化している区間でほぼ 10～15\%の 誤差範囲内でほぼ等しい増加傾向を示している.つま り箔厚が線形増加している区間では, 変形速度が速す ぎ，空気抜き板を設置したにも関わらず内部空気がほ とんど流出していない，一方，箔厚一定の区間では， 衝撃実験值がほぼ一定値を示していることに対し，空

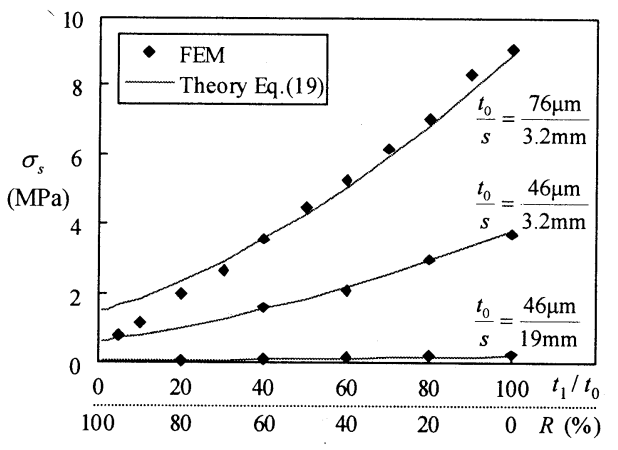

Fig. 6 Mean crushing stress for various core density

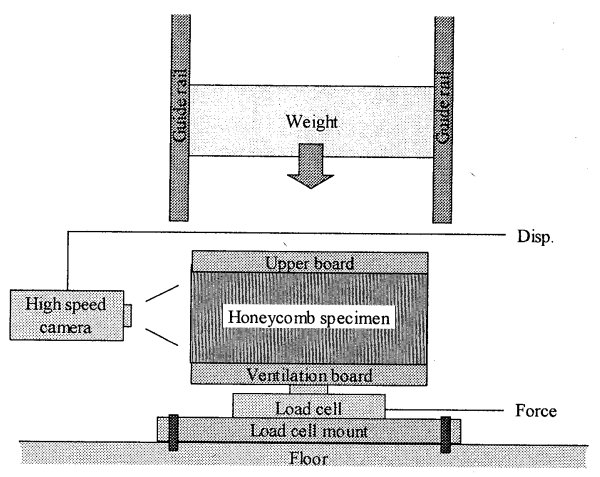

Fig. 7 Impact test using free falling weight

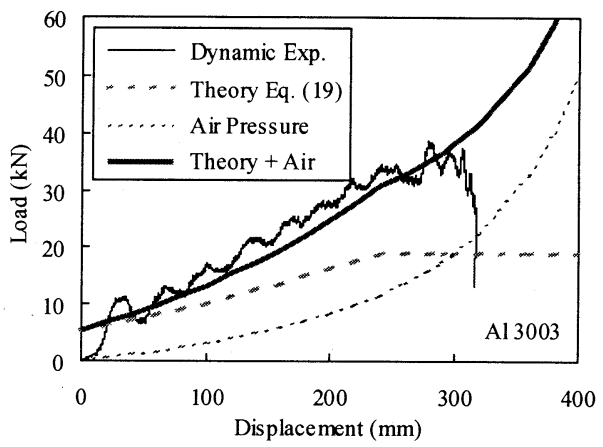

(a) $\mathrm{Al} 3003$

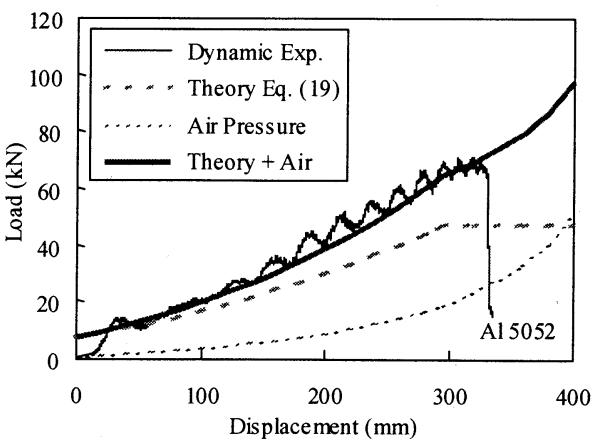

(b) $\mathrm{Al} 5052$

Fig. 8 Load vs. displacement in dynamic condtion 
気の圧力増加分を足した理論解は増加している.この 差は, 衝撃実験において, 内部空気圧力の更なる増加 と圧潰速度減少により空気漏れが発生し, 圧力の影響 が減少したためと考えられる.

空気の漏れは制御が難しく，また圧縮空気が衝撃物 の撥ね返りを招く可能性がある. 再現性のある衝撃圧 潰吸収現象を起こすためには, 内部空気の影響は減ら したい，試験片内部を真空にすることは難しいので, 試験片高さに対する変形量を抑えるか，空気抜き板の 溝をより大きくするなどの工夫が必要である.

\section{6. 結言}

セル壁をエッチング処理し䇴厚を連続的に変化さ せた減肉ハニカム材料の衝撃吸収特性について, 準静 的実験, 衝撃実験, 理論解析, 有限要素法による数值 実験を用いて調べ，以下の知見を得た。

・準静的実験での観察により, 減肉八ニカム材料の変 形機構は減肉させていないハニカム材料とほぼ等し いことを確認した.

・Wierzbicki の理論を利用し, 減肉を考慮した新しい 圧潰荷重評価式を作成した。

- 有限要素法による数值実験との比較により, 提案し た理論式が減肉率 70\%以上の範囲において, 誤差 10\% 以下で利用出来ることを示した.

・衝撃実験で得られた荷重一变位関係は, 準静的実験 用の理論式に, 内部空気の圧力増加分を加味するこ とで再現出来ることを示した.

今後は, 新しく提案した圧潰荷重評価式(19)を用い て, 所望の圧潰荷重変化をする減肉ハニカム材料を設 計できる.

落鍾式大型衝撃試験機の利用に際して防衛大学校シ ステム工学群建設環境工学科教授大野友則先生に多大 なるご協力をいただきました. 記して謝意を表します.

本論文を作成するにあたり，校閲委員からいただい たご助言に基づき提案式に改良を加えたことを記して 謝意を表します。

\section{文献}

(1) ECE Regulation No.95, Uniform Provisions Concerning the Approval of Cehicles with Regard to the Protection of the Occupants in the Event of a Lateral Collision, (2003).

(2) Ueno, M., Hatano, K., Fukushima, N. and Tsuburai, Y., Development of New Generation Mobile Deformable Barrier, JARI Research Journal, Vol. 29, No. 9 (2007), pp. 447-450.

(3) Ogasawara, N., Shiratori, M., Miyahara, S. and Yu, Q., Energy Absorption by Honeycomb Structure (1st Report, Progressive Buckling under Quasi-Static Condition), Transactions of the Japan Society of Mechanical Engineers, Series A, Vol. 63, No. 608 (1997), pp. 774-779.

(4) Yamashita, M. and Gotoh, M., Impact Behavior of Honeycomb Structures with Various Cell Specifications - Numerical Simulation and Experiment, International Journal of Impact Engineering, Vol. 32, (2005), pp. 618-630.

(5) Chen, D. H., Sakaizawa, H. and Ozaki, S., Crushing Behaviour of Hexagonal Thin-Walled Tube with Partition Plates (1st Report, Analysis of Deformation Mode), Transactions of the Japan Society of Mechanical Engineers, Series A, Vol. 72, No. 724 (2006), pp. 1978-1984.

(6) Yasui, Y., Mochida, M. and Houzouji, Y., Dynamic Axial Impact Crushing of Urethane Foam Filled Aluminum Honeycomb Members, Journal of Japan Institute of Light Metals, Vol. 54, No. 12 (2004), pp. 556-561.

(7) Satoh, T., Kobayashi, Y., Ohtsuka, T. and Tamura, H., Effect of Cell Wall Thickness on Compressive Properties of Double Layer Aluminum Honeycomb Core Sandwich Panels, Transactions of the Japan Society of Mechanical Engineers, Series A, Vol. 73, No. 730 (2007), pp. 744-750.

(8) Ueno, M., Static/Dynamic Ratio of Aluminum Honeycomb, JARI Research Journal, Vol. 28, No. 6 (2006), pp.225-230.

(9) Wierzbicki, T., Crushing Analysis of Metal Honeycomb, International Journal of Impact Engineering, Vol. 1, No. 2 (1983), pp. 171-191.

(10) McFarland, R. K., Hexagonal Cell Structures under Post-buckling Axial Load, AIAA Journal, Vol. 1, No. 6 (1963), pp. 1380-1385.

(11) Ogasawara, N., Shiratori, M., Miyahara, S., Yu, Q. and Miyano, A., Energy Absorption by Honeycomb Structure (2nd Report, Evaluation of Collapsing Stress under Impact Condition), Transactions of the Japan Society of Mechanical Engineers, Series A, Vol. 63, No. 616 (1997), pp. 2575-2579. 